\title{
Fluorescent in situ hybridization (FISH) as a diagnostic tool for Williams-Beuren syndrome
}

\author{
Deise Helena de Souza ${ }^{1}$, Danilo Moretti-Ferreira ${ }^{1}$ and Lígia Maria Suppo de Souza Rugolo ${ }^{2}$ \\ ${ }^{1}$ Serviço de Aconselhamento Genético, Departamento de Genética, Instituto de Biociências, \\ Universidade Estadual Paulista, Botucatu, SP, Brasil. \\ ${ }^{2}$ Departamento de Pediatria, Faculdade de Medicina, Universidade Estadual Paulista, Botucatu, SP, Brasil.
}

\begin{abstract}
Fluorescent in situ hybridization (FISH) with commercial probes covering the elastin gene (ELN) was used to determine the frequency of the 7q11.23 deletion in 18 children clinically diagnosed with Williams-Beuren syndrome (WBS). A de novo deletion was detected in 15 of the children (83\%). Diagnostic investigation for WBS started late in childhood (median $=5.8$ years). All the children showed facial features typical of the syndrome, mental retardation and developmental delay. Over-friendliness was observed in the majority of cases. Clinodactyly of the 5th finger $(n=13)$, cardiovascular disease $(n=9)$, loquacity $(n=9)$, low birthweight $(n=8)$, and failure to thrive $(n=9)$ were observed only in those children with the deletion. Respiratory problems $(n=9)$, though not previously reported in the literature, was a common finding in the group studied. Our results confirmed that FISH is useful in identifying $7 q 11.23$ deletions in cases of WBS. Clinical manifestations were more evident in the deletion-positive children
\end{abstract}

Key words: 7q11.23 deletion, ELN, FISH, Williams-Beuren syndrome.

Received: December 13, 2005; Accepted: July 25, 2006.

Williams-Beuren syndrome (WBS) comprises characteristic "elfin" facies (Figure 1), mental retardation, failure to thrive, congenital heart disease, unusual neurobehavioral features, learning disabilities and infantile hypercalcemia, with the clinical phenotype changing with advancing age so that its clinical diagnosis may not be suspected during early infancy (Williams et al., 1961; Beuren et al., 1962; Black et al., 1963; Kelly et al., 1975; Burn, 1986). The incidence of WBS has been estimated to be 1 in 20,000 to 50,000 live births. Cases are generally sporadic, though autosomal dominant inheritance has been reported (Cortada et al., 1980; Morris et al., 1993).

The multisystem phenotype of WBS is associated with a $1.5 \mathrm{Mb}$ deletion at $7 \mathrm{q} 11.23$ that includes the elastin gene (ELN) and at least 21 other genes (Merla et al. 2002). The contribution of each of these genes to the WBS phenotype is not known, but $E L N$ has been proven to be associated with congenital heart disease (Ewart et al., 1993; Lowery et al., 1995; Anon., 2001; Sugayama et al, 2003; Heller et al., 2003). Even though at least $95 \%$ of WBS individuals with the classical phenotype carry an apparently identical $1.5 \mathrm{Mb}$ deletion, several individuals presenting classical WBS and a smaller deletion have been described,

Corresponding author: Danilo Moretti-Ferreira, Departamento de Genética Inst. Biociências UNESP, Distrito de Rubião Júnior s/n, 18618-000 Botucatu, SP, Brazil. E-mail sag@fmb.unesp.br. suggesting that the critical WBS region is smaller than 1.5 Mb (Osborne, 1999; Heller et al., 2003)

The purpose of this study was to establish the frequency of the 7q11.23 deletion in children with clinically suspected WBS, who were referred to the Genetic Counseling Service of the Botucatu Institute of Biosciences, Brazil, between 1986 and 2002. The research protocol was approved by the Botucatu Medical School Research Ethics Committee - São Paulo State University, and parental consent was obtained.

All the children were clinically examined using a checklist of the most typical WBS features (Morris et al., 1988; Jones and Smith, 1975). They were submitted to neurological, ophtalmological and cardiological (echocardiography and measurement of serum calcium levels) evaluations. Parents provided information on the children concerning pregnancy, birth conditions and developmental milestones. Data from previous medical records were obtained. Post-natal growth was classified according to the National Center for Health Statistics Charts (2000) and head circumference according to Nellhaus (1968).

Of the 25 children referred with the diagnostic hypothesis of WBS, 18 were selected for the study based on the checklist of WBS features. The inclusion criteria were the presence of two of the three most frequent WBS features (typical facial features, heart disease and develop- 
mental delay/behavioral problems) associated with a least two other less common features (failure to thrive, hypercalcemia, gastrointestinal, genitourinary, ophthalmologic, auditory, dermatologic, musculoskeletal and dental problems). All the 18 children showed typical facial features (broad forehead, wide mouth, full prominent lips, periorbital fullness), mental retardation and behavioral problems, principally over-friendliness.

Chromosome analysis was performed after highresolution GTG banding (Yunis, 1976) in cultured peripheral blood lymphocytes. Fluorescent in situ hybridization (FISH) was performed using commercial Williams Syndrome Region probes encompassing ELN. The Vysis ${ }^{\circledR}$ probe (Cat No 32-190041, Vysis, USA) is approximately $180 \mathrm{~kb}$ in size and contains the ELN and LIM-Kinase 1 (LIM-K1) genes and the D7S613 locus, the control probe contains the D7S486 and D7S522 loci. The Cytocell® Williams-Beuren $450 \mathrm{~kb}$ probe (Cat No LPU 011, Cytocell, USA) consists of three non-overlapping clones from genes FZD9 to CYLN2, does not include ELN, and contains the chromosome 7 centromere $\alpha$-satellite D7Z1 probe for con-

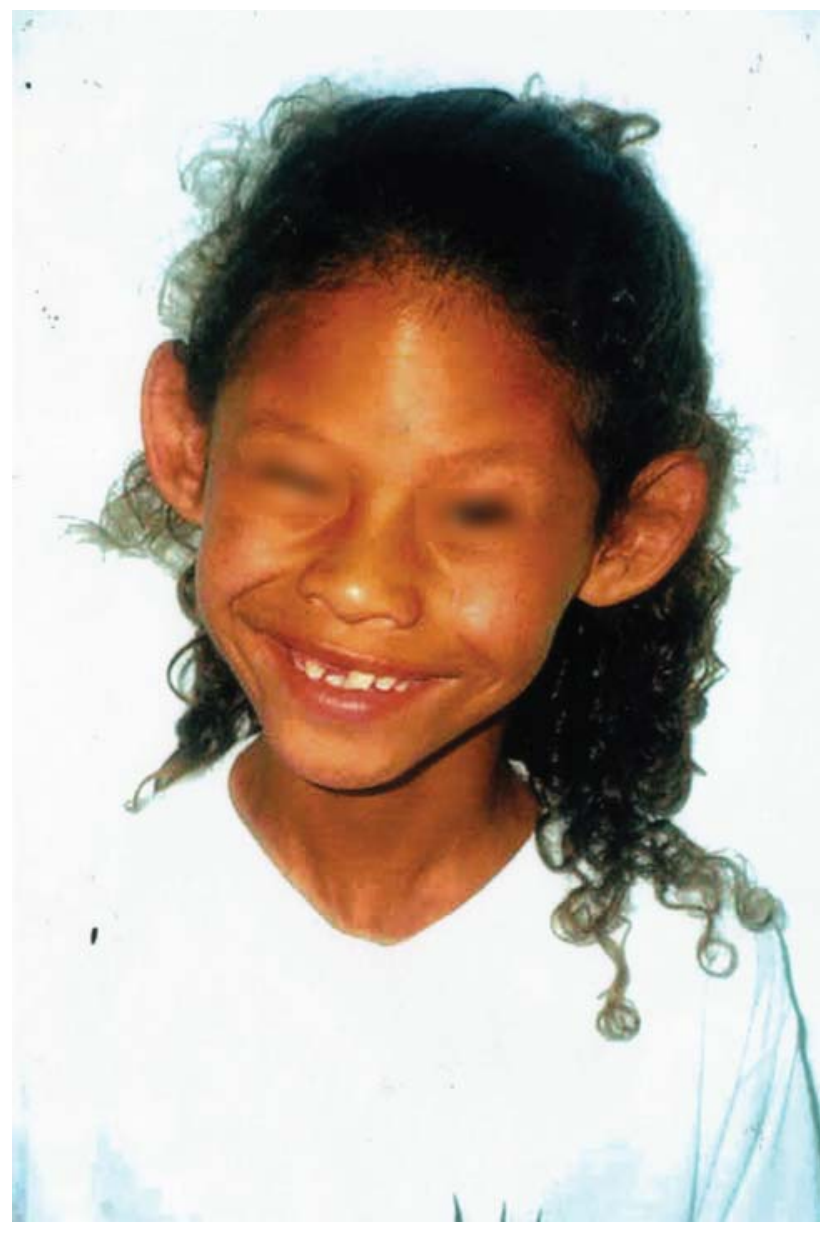

Figure 1 - Typical facial appearance of individuals with Williams Beuren syndrome (WBS): broad forehead, large and anteverted ears, flat nasal bridge, wide mouth, full cheeks, full prominent lips, dental anomalies, small jaw. trol. Whenever a deletion was detected, high-resolution GTG banding and FISH of the parents of the child were carried out.

Our GTG-banding analysis revealed normal karyotypes in the 18 children and their parents. Cytocell probe FISH analysis showed a $7 \mathrm{q} 11.23$ deletion in 15 children. The absence of a deletion in the three remaining children was confirmed by FISH with the Vysis probe, which was also used to retest 6 (Figure 2) of the 15 children identified as deletion-positive by the Cytocell probe and confirmed the diagnosis. This high deletion frequency is in agreement with previously reported data (Borg et al., 1995; Elçioglu et al., 1998; Sugayama et al., 2004a). Parents did not carry the deletion, thus confirming the de novo nature of this rearrangement.

The main clinical findings for the children are summarized in Table 1. Only deletion-positive children were small for gestational age ( 8 out of 15 ), and remained small with aging ( 7 out of 15 ). Head circumference was below the $2^{\text {nd }}$ centile in 7 out of the 15 deletion-positive children and in one of the three deletion-negative children. There is a characteristic pattern of prenatal and postnatal growth deficiency in children with WBS, and weight and height are clearly below the normal range from birth to adulthood (Lashkari et al., 1999). In our series of cases, low stature and weight ( 5 centile) were detected in 7 out of 15 and 4 out of 15 deletion-positive children, respectively. Furthermore, feeding difficulties (11 out of 15), chronic constipation (12 out of 15), and failure to thrive (9 out of 15) were highly prevalent findings.

Nine of the 15 children $(60 \%)$ with $E L N$ deletion showed cardiovascular defects, and six of them had supravalvular aortic stenosis confirmed by echocardiogram. Other cardiopathies observed included aortic coarctation (1

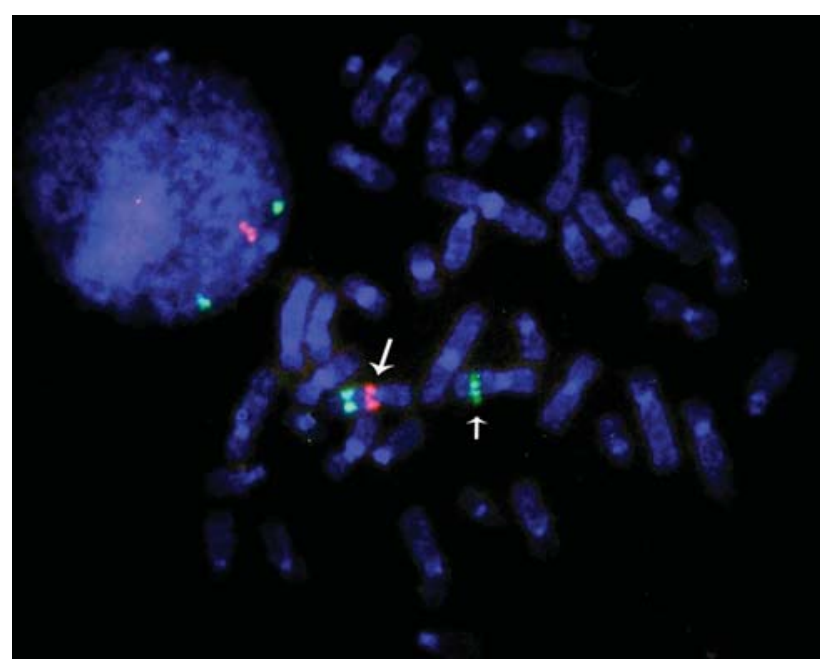

Figure 2 - Metaphase after fluorescent in situ hybridization (FISH)with VYSIS $®$ Williams Syndrome Region. The normal chromosome (long arrow) shows a pink signal at 7q11.23, and a green signal at the control segment. On the abnormal chromosome 7 (small arrow), only the control green signal is observed, indicating a deletion at $7 \mathrm{q} 11.23$. 
Table 1 - Clinical findings related with the Williams Beuren syndrome (WBS) children in our study with and without the 7q11.23 deletion compared with data from the literature*.

\begin{tabular}{|c|c|c|c|c|}
\hline \multirow[b]{3}{*}{ Clinical feature } & \multicolumn{2}{|c|}{ Deletion-positive } & \multicolumn{2}{|c|}{ Deletion-negative } \\
\hline & $\begin{array}{l}\text { Our study } \\
(\mathrm{n}=15)\end{array}$ & $\begin{array}{c}\text { Lit* }^{*} \\
(\mathrm{n}=379)\end{array}$ & $\begin{array}{l}\text { Our study } \\
(\mathrm{n}=3)\end{array}$ & $\begin{array}{c}\text { Lit* } \\
(\mathrm{n}=138)\end{array}$ \\
\hline & & $\%$ & & $\%$ \\
\hline Broad forehead & 15 & 93 & 3 & 38 \\
\hline Wide mouth & 15 & 93 & 3 & 40 \\
\hline Full prominent lips & 15 & 94 & 3 & 42 \\
\hline Periorbital fullness & 13 & 93 & 3 & 36 \\
\hline Long philtrum & 12 & 91 & 1 & 36 \\
\hline Malar hypoplasia & 12 & 100 & 2 & 92 \\
\hline Flat nasal bridge & 11 & 91 & 3 & 90 \\
\hline Dental anomalies & 10 & 64 & 2 & 32 \\
\hline Full cheeks & 10 & 87 & 3 & 44 \\
\hline Bitemporal narrowing & 8 & 88 & 2 & 32 \\
\hline Strabismus & 8 & 51 & 1 & 7 \\
\hline Anteverted ears & 7 & - & 1 & - \\
\hline Microcephaly & 6 & 45 & 1 & 38 \\
\hline Small jaw & 6 & 89 & 2 & 43 \\
\hline Stellate iris & 3 & 39 & 0 & 23 \\
\hline $\begin{array}{l}\text { Clinodactyly of the } 5^{\text {th }} \\
\text { finger }\end{array}$ & 13 & 56 & 0 & 43 \\
\hline Mental retardation & 15 & 86 & 3 & 66 \\
\hline Over-friendliness & 13 & 83 & 3 & 35 \\
\hline $\begin{array}{l}\text { Small for gestational } \\
\text { age }\end{array}$ & 8 & 69 & 0 & 17 \\
\hline Stature & 7 & 65 & 0 & 40 \\
\hline Weight & 4 & 50 & 0 & 35 \\
\hline Feeding difficulties & 11 & 73 & 1 & 23 \\
\hline Chronic Constipation & 12 & 57 & 2 & 24 \\
\hline Hyperactivity & 11 & 75 & 3 & 44 \\
\hline $\begin{array}{l}\text { Inguinal/ umbilical } \\
\text { hernia }\end{array}$ & 9 & 34 & 2 & 18 \\
\hline Loquacity & 9 & 54 & 0 & 14 \\
\hline Hoarse voice & 8 & 74 & 2 & 26 \\
\hline Failure to thrive & 9 & 57 & 0 & 43 \\
\hline Hypotonia & 7 & 72 & 1 & 57 \\
\hline Respiratory problems & 7 & - & 2 & - \\
\hline $\begin{array}{l}\text { Supravalvular aortic } \\
\text { stenosis }\end{array}$ & 6 & 60 & 0 & 10 \\
\hline Other cardiopathy & 3 & 43 & 0 & 32 \\
\hline Vomiting & 5 & 73 & 1 & 23 \\
\hline Chronic otitis media & 4 & 29 & 0 & 0 \\
\hline Renal problems & 4 & 18 & 0 & 8 \\
\hline
\end{tabular}

* Modified from Sugayama et.al. (2004b); - not reported. Lit: The literature.

out of 15) and atrio-ventricular communication (2 out of 15). Cardiovascular abnormalities are very frequent (53-80\%) in WBS individuals, and $E L N$ deletion has been associated with the typical vasculopathy of WBS, namely supravalvular aortic stenosis and pulmonary arterial steno- sis (Ewart et al., 1994; Eronen et al., 2002; Sugayama et al., 2003). However, a considerable number of the WBS-associated cardiovascular problems, including supravalvular aortic stenosis, may not manifest until adulthood and the symptoms might be missing or non-specific, misleading the diagnosis for years. The frequency of cardiovascular abnormalities depends on accurate cardiovascular evaluation (Ino et al., 1988; Lowery et al., 1995, Eronen et al., 2002; Sugayama et al., 2003).

Serum calcium was measured in all the children but hypercalcemia $\left(11.2 \mathrm{mg} \mathrm{dL}^{-1}\right)$ was detected in only one child, who was under one year of age.

Most of the children showed respiratory problems, particularly bronchospasms, bronchitis and episodes of pneumonia. To our knowledge, these symptoms have not been previously reported. The possibility of a casual association cannot be ruled out because respiratory complaints are very frequent in pediatric visits. Nonetheless, closer attention should be paid to this feature in future studies.

The diagnosis of WBS is often late (Morris et al., 1988; Huang et al., 2002). This fact was confirmed in our series of cases, with age at first diagnosis ranging from 16 months to 12 years with a mean of 5 years. Only three children were diagnosed below the age of 3 years, and in nine children, the diagnosis was made after the age of 7 years, even though they met the Lowery criteria for classic WBS (Lowery et al., 1995), had developmental delay and learning difficulties and attended special schools. The delay in establishing WBS diagnosis may be explained by some of the following factors: (1) WBS physical manifestations are subtle and may not be apparent at an early age, making diagnosis difficult in infants and young children who lack classic manifestations such as supravalvular aortic stenosis and hypercalcemia; (2)infantile hypercalcemia is probably under-diagnosed as it manifests itself during the first year of life as failure to thrive, persistent vomiting, irritability, colic and intestinal constipation that are common problems during infancy (Martin et al., 1984; Morris et al., 1988; Lashkari et al., 1999; American Academy of Pediatrics, 2001; Carrasco et al., 2005); and (3) although these children exhibit developmental delay, variable degrees of mental retardation and visual spatial impairment, their hyperactivity, loquacity and over-friendliness may suggest that their intellectual ability is better than it actually is (Jones and Smith, 1975; Udwin et al., 1976; Morris et al., 1998; Carrasco et al., 2005).

In conclusion, this study confirmed the delay in clinical diagnosis and the usefulness of FISH in the detection of the $7 \mathrm{q} 11.23$ deletion in children with WBS.

\section{Acknowledgments}

This research was supported by the Brazilian agency Fundação Lucentis de Apoio a Cultura, Ensino, Pesquisa e Extensão. 


\section{References}

Anon (2001) American Academy of Pediatrics. Health care supervision for children with Williams syndrome. Pediatrics 107:1192-1204.

Beuren AJ, Apitz J and Harmjanz D (1962) Supravalvular aortic stenosis in association with mental retardation and certain appearance. Circulation 26:235-240.

Black JA and Bonham-Carter RE (1963) Association between aortic stenosis and facies of several infantile hipercalcemia. Lancet ii:745-749.

Borg I, Delhanty DA and Araitser M (1995) Detection of hemizygosity at the elastin locus by FISH analysis as a diagnostic test in both classical and atypical cases of Williams syndrome. J Med Genet 32:692-696.

Burn J (1986) Williams syndrome. J Med Genet 23:389-395.

Carrasco X, Castillo S, Aravena T, Rothhammer P and Aboitiz F (2005) Williams syndrome: Pediatric, neurologic and cognitive development. Pediat Neurol 32:166-172.

Cortada X, Taysi K and Hartman AF (1980) Familial Williams syndrome. Clin Genet 18:173-176.

Elçioglu N, Mackie-Ogilvie C, Daker M and Berry AC (1998) FISH analysis in patients with clinical diagnosis of Williams syndrome. Acta Paediatr 87:48-53.

Eronen M, Peipo M, Hiipala A, Raatukka M, Arvio M, Johansson R and Käkönen M (2002) Cardiovascular manifestations in 75 with Williams syndrome. J Med Genet 39:554-558.

Ewart AK, Morris CA, Atckinson D, Jin W, Sternes K, Spallone P, Stock AD, Leppert M and Keating MT (1993). Hemizygosity at the elastin locus in an developmental disorder, Williams Syndrome. Nat Genet 5:11-16.

Ewart KA, Jin W, Atkinson D, Morris CA and Keating MT (1994) Supravalvular aortic stenosis associated with a deletion disrupting the elastin gene. J Clin Invest 93:1071-1077.

Heller R, Rauch A, Lüttgen S, Schröder B and Winterpacht A (2003) Partial deletion of the critical 1,5 Mb interval in Williams-beuren syndrome. J Med Genet 40:e99.http://www. jmedgenet.com/cgi/content/full/40/8e99 (1/29/2004).

Huang L, Sadler L, O Riordan MA and Robin NH (2002) Delay in diagnosis of Williams syndrome. Clin Pediat 41:257-261.

Ino T, Nishimoto K, Iwahara M, Akimoto K, Boku K, Kaneko K, Tokita A and Tanaka J (1988) Progressive vascular lesions in Williams-Beuren syndrome. Pediatr Cardiol 9:55-58.

Jones KL and Smith DW (1975) The Williams elfin facies syndrome. J Pediatr 86:718-723.

Kelly JR, Barr ES and Anderson RC (1975) The elfin facies syndrome. Oral Surg 40:205-218.

Lowery MC, Morris CA, Ewart AK, Brothman LJ, Zhu XL, Leonard CO, Carey JC, Keating M and Brothman AR (1995) Strong correlation of elastin deletions, detected by FISH, with Williams Syndrome: Evaluation of 235 patients. Am J Hum Genet 57:49-53.
Lashkari A, Smith AK and Graham JR JM (1999) WilliamsBeuren syndrome: An update and review for the primary physician. Clin Pediatr 38:189-208.

Martin NDT, Snodgrass GJAI and Cohen RD (1984) Idiopathic infantile hypercalcemia: A continuing enigma. Arch Dis Child 59:605-613.

Merla G, Ucla C, Guipponi M and Reymond A (2002) identification of additional transcripts in the Williams-beuren syndrome critical region. Hum Genet 110:429-438.

Morris CA, Demsey S, Leonard CO, Dilts C and Blackburn BL (1988) Natural history of Williams syndrome: Phisical characteristics. J Pediatr 113:318-326.

Morris CA, Thomas IT and Greenberg E (1993) Williams syndrome; autosomal dominant inheritance. Am J Med Genet 47:478-481.

Morris CA, Lu X and Greenberg F (1998) Syndromes identified in patients whit a previous diagnosis of Williams syndrome who do not have elastin deletion. Proc Greenwood Genet Cent 17:116-117.

Nellhaus G (1968) Head circumference from birth to eighteen years. Practical composite international and interracial graphs. Pediatrics 41:106-114.

Nickerson E, Greenberg F, Keating MT, Mccaskill C and Shaffer LG (1995) Deletions of the elastin gene at 7q11.22 occur in approximately $90 \%$ of patients with Williams syndrome. Am J Med Genet 56:1156-1161.

Osborne LR (1999) Williams-Beuren Syndrome: Unraveling the mysteries of a microdeletion disorder. Mol Genet Metab 67:1-10.

Sugayama SMM, Moises RL, Wagënfur J, Ikari NM, Abe KT, Leone C, Silva CAA, Chauffaille MLLF and Kim CA (2003) Williams-Beuren Syndrome. Cardiovascular abnormalities in 20 patients diagnosed with fluorescence in situ hybridization. Arq Bras Cardiol 81:468-473.

Sugayama SMM, Koch VHK, Furusama EA, Leone C and Kim CA (2004a) Renal and urinary findings in 20 patients with Williams-Beuren syndrome diagnosed by fluorescence in situ hybridization (FISH). Rev Hosp Clin 59:266-272.

Sugayama SMM, Leone C and Kim CA (2004b) Willimas-Beuren Syndrome: A clinical diagnostic score proposal. Rev Paul Ped 22:137-145.

Udwin O, Davies M and Howlin P (1976) A longitudinal study of cognitive abilities and educational attainment in Williams syndrome. Dev Med Child Neurol 38:1020-1029.

Williams JCP, Barratt-Boyes BG and Love JB (1961) Supravalvular aortic stenosis. Circulation 21:1311-1318.

Yunis JJ (1976) High resolution chromosome. Science 191:1268-1270.

\section{Internet resources}

National Center for Health Statistics, http://www.cdc.gov/ growthcharts (11/7/2000). Editor: Angela M. Vianna-Morgante 